\title{
Prevalence of hypertensive disorders of pregnancy and its maternal outcome in a tertiary care hospital, Salem, Tamil Nadu, India
}

\author{
Subha Sivagami Sengodan*, Sreeprathi N.
}

Department of Obstetrics and Gynecology, Government Mohankumaramangalam Medical College Hospital, Salem, Tamil Nadu, India

Received: 19 October 2019

Revised: 23 November 2019

Accepted: 02 December 2019

*Correspondence:

Dr. Subha Sivagami Sengodan,

E-mail: drppsamysubha@gmail.com

Copyright: ( $)$ the author(s), publisher and licensee Medip Academy. This is an open-access article distributed under the terms of the Creative Commons Attribution Non-Commercial License, which permits unrestricted non-commercial use, distribution, and reproduction in any medium, provided the original work is properly cited.

\section{ABSTRACT}

Background: Hypertensive disorders complicate 5-10\% of all pregnancies and together forms the deadly triad- along with hemorrhage and heart disease that contributes greatly to maternal morbidity and mortality. Objective of this study was to determine the prevalence of hypertensive disorders of pregnancy and its maternal complications in patients attending obstetrics and gynaecology department, Government Mohan Kumaramangalam Medical College Hospital, Salem.

Methods: This is a prospective study conducted from August 2018 to July 2019 in the department of obstetrics and gynaecology. Patients diagnosed with hypertensive disorders of pregnancy was evaluated and data were collected.

Results: A total of 19,383 pregnant women visited obstetrics and gynaecology department over a period of one year, out of which 2028 were diagnosed with hypertensive disorders of pregnancy. Hence the prevalence of hypertensive disorders in pregnancy is $10.4 \%$. Among 2028 hypertensive disorder cases, Gestational hypertension were 962 cases (47.4\%), pre-eclampsia 661 cases $(32.6 \%)$, chronic hypertension 166 cases $(8.2 \%)$ and pre-eclampsia superimposed on chronic hypertension 239 cases $(11.8 \%)$. The prevalence was highest among primigravida (54\%) compared to multigravida (46\%). Hypertensive disorders were highest among the age group of 18-22 years in our study. Most common maternal complication in our study was HELLP syndrome.

Conclusions: Prevalence of hypertensive disorders was high in our study. Early detection and timely intervention decrease the maternal complications.

Keywords: Gestational hypertension, Outcome, Pre-eclampsia, Prevalence, Systolic and diastolic blood pressure

\section{INTRODUCTION}

Hypertensive disorders complicate $5-10 \%$ of all pregnancies and together forms the deadly triad- along with hemorrhage and heart disease that contributes greatly to maternal morbidity and mortality. ${ }^{1}$ WHO reported $14 \%$ of maternal death attributed to hypertensive disorders of pregnancy. ${ }^{2}$ ACOG classified hypertensive disorders of pregnancy into four groups. ${ }^{3}$ (1) Gestational hypertension: diagnosed when systolic blood pressure > $140 \mathrm{mmHg}$ or diastolic blood pressure > $90 \mathrm{mmHg}$ measured on two occasions four to six hours apart after 20 weeks of pregnancy in absence of proteinuria or systemic signs and symptoms. (2) Pre-eclampsia: systolic blood pressure $>140 \mathrm{mmHg}$ or diastolic blood pressure > $90 \mathrm{mmHg}$ with proteinuria with or without systemic signs and symptoms/eclampsia (pre-eclampsia with convulsion). (3) Chronic hypertension: systolic blood pressure $>140 \mathrm{mmHg}$ or diastolic blood pressure $>90$ $\mathrm{mmHg}$ present pre-pregnancy or $<20$ weeks of gestational age. (4) Pre-eclampsia superimposed on Chronic hypertension: increased blood pressure and new 
onset proteinuria or other end organ dysfunction in addition to pre-existing hypertension.

The main maternal and fetal risk associated with hypertensive disorders of pregnancy include HELLP syndrome, abruptio placenta, pulmonary edema, postpartum hemorrhage, acute renal failure, preterm delivery, fetal growth restriction, perinatal death. ${ }^{4}$ HELLP syndrome characterised by hemolysis, elevated liver enzymes and low platelet count. HELLP syndrome is diagnosed when lactate dehydrogenase is more than $600 \mathrm{U} / \mathrm{L}$, peripheral blood smear showing schistocytes, burr cells and helmet cells, alanine and aspartate transaminase levels are more than two times the upper limit of normal, serum bilirubin more than $1.2 \mathrm{mg} / \mathrm{dl}$ and platelet less than 100x103/microL.

\section{METHODS}

This is a prospective study conducted in the department of obstetrics and gynaecology, Government Mohan Kumaramangalam Medical College Hospital, Salem, over a period of one year from August 2018 to July 2019. All pregnant women attending outpatient department were screened for hypertensive disorders of pregnancy and evaluated. Patients subjected to detailed history taking, general examination, systemic and obstetric examination. Blood pressure was measured as per standard guidelines for all pregnant women and all necessary investigations taken to categories the patients into gestational hypertension, pre-eclampsia, chronic hypertension, preeclampsia superimposed on chronic hypertension. All patients with hypertensive disorders of pregnancy in our study were treated with anti-hypertensives. All cases of severe preeclampsia/eclampsia were treated with $\mathrm{MgSO}_{4}$ Pritchards or zuspan regimen. Fetal wellbeing and amniotic fluid volume evaluated by physical examination and sonography. Dexamethasone were given to patients less than 37 weeks of gestation for fetal lung maturity. Cases beyond 37 weeks of gestation are planned for delivery. Cases of severe preeclampsia demands termination of pregnancy. Obstetric management done following standard protocols. Maternal outcome in terms of complications like HELLP syndrome, abruptio placenta, pulmonary edema, postpartum hemorrhage and acute renal failure were noted. This is a prospective observational study confirmed by chi square test.

\section{Inclusion criteria}

- All pregnant women attending department of obstetrics and gynaecology who were diagnosed as hypertensive disorders of pregnancy were taken for this study.

\section{Exclusion criteria}

- Patients diagnosed with other causes of convulsion were excluded in this study.

\section{RESULTS}

A total of 19,383 pregnant women visited ante-natal clinic over a period of one year from August 2018 to July 2019. Out of which 2028 cases (10.4\%) diagnosed with hypertensive disorders of pregnancy.

Table 1: Prevalence of hypertensive disorders.

\begin{tabular}{|lll|}
\hline Types of hypertensives disorders & $\begin{array}{l}\text { No. of } \\
\text { cases }\end{array}$ & $\%$ \\
\hline Gestational hypertension & 962 & $47.4 \%$ \\
\hline Pre-eclampsia & 661 & $32.6 \%$ \\
\hline Chronic hypertension & 166 & $8.2 \%$ \\
\hline $\begin{array}{l}\text { Pre-eclampsia superimposed on } \\
\text { chronic hypertension }\end{array}$ & 239 & $11.8 \%$ \\
\hline
\end{tabular}

Table 1 shows prevalence of hypertensive disorders in which gestational hypertension (47.4\%) was most common followed by pre-eclampsia (32.6\%), preeclampsia superimposed on chronic hypertension $(11.8 \%)$ and chronic hypertension (8.2\%).

Table 2: Age distribution of cases.

\begin{tabular}{|lll|}
\hline Maternal age (in years) & Number of cases & $\%$ \\
\hline $18-22$ & 804 & $39.6 \%$ \\
\hline $23-27$ & 616 & $30.4 \%$ \\
\hline $28-32$ & 335 & $16.5 \%$ \\
\hline$>33$ & 273 & $13.5 \%$ \\
\hline
\end{tabular}

Table 2 shows age distribution of cases, in which hypertensive disorders were highest in the age group of $18-22$ years of age $(39.6 \%)$ followed by $30.4 \%$ of patients in the age group of 23-27 years of age, $16.5 \%$ of patients in the age group of 28-32 years of age and $13.5 \%$ of patients in the age group of more than 33 years of age.

Table 3: Gravida wise distribution.

\begin{tabular}{|lll|}
\hline Gravidity status & Number of cases & $\%$ \\
\hline Primi & 1095 & $54 \%$ \\
\hline Multi & 933 & $46 \%$ \\
\hline
\end{tabular}

Table 3 shows gravida wise distribution, majority were seen among primigravida (54\%) than multigravida $(46 \%)$.

Table 4: Case distribution according to maternal complication.

\begin{tabular}{|lll|}
\hline Complications & Number of cases & $\%$ \\
\hline HELLP syndrome & 129 & $6.4 \%$ \\
\hline Abruptio placenta & 95 & $5.0 \%$ \\
\hline Pulmonary edema & 85 & $4.2 \%$ \\
\hline Postpartum hemorrhage & 58 & $2.9 \%$ \\
\hline Acute renal failure & 220 & $1 \%$ \\
\hline
\end{tabular}


Table 4 shows case distribution according to maternal complication, most common maternal complication in our study was HELLP syndrome $(6.4 \%)$ followed by abruptio placenta (5\%), pulmonary edema (4.2\%), postpartum hemorrhage $(2.9 \%)$ and acute renal failure $(1 \%)$.

\section{DISCUSSION}

Hypertensive disorders of pregnancy cause most detrimental effect on both mother and fetus. This disease is one of the major public health problems responsible for increase in maternal and perinatal morbidity and mortality. Some of the risk factors for preeclampsia are primi paternity, extremes of maternal age, multifetal gestation, pregnancies through assisted reproductive technique, pre-eclampsia in previous pregnancies, renal disease, connective tissue disorders and family history of pre-eclampsia. Smoking reduces the risk of hypertension during pregnancy. ${ }^{5}$ Primary cause behind pre-eclampsia is failure of second wave of cytotrophoblastic invasion of spiral arterioles in the muscular layer. Other causes include immunological intolerance between maternal, placental and fetal tissues, maternal maladaptation to inflammatory or cardiovascular changes of normal pregnancy and genetic influences.

In this study, overall prevalence of hypertensive disorders of pregnancy were $10.4 \%$, gestational hypertension was diagnosed in 962 cases $(47.4 \%)$, pre-eclampsia 661 cases (32.6\%), chronic hypertension 166 cases $(8.2 \%)$, severe pre-eclampsia superimposed on chronic hypertension 239 cases $(11.8 \%)$. Incidence of pre-eclampsia in India in hospital practice varies from 5-15\% and eclampsia about $1.5 \% .^{6}$ Bindu $\mathrm{K}$ et al, reported the prevalence of PIH was $10.7 \%$ among primipara and $9.1 \%$ among multipara. ${ }^{7}$ In the present study, the incidence was $39.6 \%$ in the age group of $18-22$ years, $30.4 \%$ in the age group of $23-27$ years. In Gogaram et al study highest incidence of hypertensive disorders occurred among 23-27 years of age group. ${ }^{8}$ In our study the prevalence were highest among primigravida (54\%) compared to multigravida (46\%). Kolluru V et al, reported in their study that incidence of hypertensive disorders in primigavida as $48.3 \%$ and multigravida as $50.9 \% .^{9}$

The present study revealed that HELLP syndrome as commonest maternal complication affecting $6.4 \%$ and abruptio placenta were next common complication affecting $4.7 \%$. Other major complications included pulmonary edema $4.2 \%$, post-partum hemorrhage $2.9 \%$ and acute renal failure $1 \%$. Gandhi MR et al, reported eclampsia as a most common complication affecting $11.6 \%$ followed by HELLP syndrome $5.26 \%$, abruptio placenta $5.26 \%$ and post-partum hemorrhage $5.26 \% .^{10}$ Adu-Bonsaffoh $\mathrm{K}$ et al, reported that $31.7 \%$ of mothers died of hypertensive disorders of pregnancy. ${ }^{11}$

\section{CONCLUSION}

Hypertensive disorders of pregnancy are the major health problem and it is the major cause contributing to maternal morbidity and mortality. Gestational hypertension cannot be prevented but development of pre-eclampsia and its complications can be prevented through early diagnosis and proper management, thereby reducing maternal morbidity and mortality. Though the prevalence of preeclampsia are on declining trend, it pose a major contributor of poor maternal and fetal outcome. Early detection of cases through proper antenatal checkup at all health care levels along with early initiation of antihypertensive drugs to overcome adverse maternal outcome. Proper follow up of cases helps to prevent its maternal and fetal complications.

\section{Funding: No funding sources \\ Conflict of interest: None declared}

Ethical approval: The study was approved by the Institutional Ethics Committee

\section{REFERENCES}

1. Cunningham FG, Lenovo KJ, Bloom SL, Dashe JS, Hoffman BL, Catherine YS. Williams Obstetrics. $25^{\text {th }}$ ed. New York, NY: Mc Graw Hill Companies; 2018:710-754.

2. Say L, Chou D, Gemmill A, Moller AB, Daniels J, Temmerman M, et al. Global causes of maternal death: a WHO systematic analysis. Lancet Glob Health. 2014;2(6):323-33.

3. Roberts JM, August PA, Bakris G, Barton JR, Bernstein IM, Druzin M, et al. Hypertension in pregnancy. Report of the American college of obstetricians and gynecologists' task force on hypertension in pregnancy. Obstet Gynecol. 2013;122(5):1122-31.

4. James D, Steer PJ, Weiner CP, Gonik B, Crowther CA, Robson SC. High risk pregnancy management options.4th edition; Elsevier Saunders; 2011:599626.

5. Powe CE, Levine RJ, Karumanchi SA. Preeclampsia, a disease of the maternal endothelium: The role of antiangiogenic factors and implications for later cardiovascular disease. Circulation. 2011;123:285669.

6. Nobis PN, Hajong A. Eclampsia in India through the decades. J Obstet Gynaecol India. 2016;66:172-6.

7. Bindu KH, Devi EH. Effect of pregnancy induced hypertension on pregnancy outcome: a hospital based cross sectional study at a tertiary care hospital. Int $\mathbf{J}$ Reprod Contracept Obstet Gynecol. 2018;7950:1984-7.

8. Gogaram, Prasad H, Misha S. Prevalence of pregnancy induced hypertension in Churu District. Indian J Basic Appl Med Res. 2018;7(3):271-6.

9. Kolluru V, Ramya Y, Harika, Kaul R. Maternal and perinatal outcome associated with pregnancy induced 
hypertension. Int $\mathbf{J}$ Reprod Contracept Obstet Gynecol. 2016;5(10):3367-71.

10. Gandhi M, Jani P, Patel U, Kakani C, Thakor N, Gupta N. Perinatal outcome in pregnancy induced hypertension cases at GMERS medical college, Dharpur-Patan, North Gujarat Region, India: a prospective study. Int J Adv Med. 2015;2(2):152-5.

11. Adu-Bonsaffoh K, Oppong SA, Binlinla G, Obed SA. Maternal deaths attributable to hypertensive disorders in a tertiary hospital in Ghana. Int $\mathbf{J}$ Gynecol Obstet. 2013;123(2):110-3.

Cite this article as: Sengodan SS, Sreeprathi N..

Prevalence of hypertensive disorders of pregnancy and its maternal outcome in a tertiary care hospital, Salem, Tamil Nadu, India. Int J Reprod Contracept Obstet Gynecol 2020;9:236-9. 